\title{
Are Measurements of Urine Enzymes Useful during Aminoglycoside Therapy?
}

\author{
MICHAEL D. REED, MARY W. VERMEULEN, ROBERT C. STERN, P. W. CHENG, \\ STEPHEN H. POWELL, AND THOMAS F. BOAT ${ }^{(33)}$ \\ Departments of Pharmacy Services [M.D.R.], Pediatrics [M.D.R., M.W.V., R.C.S., P.W.C., T.F.B.], and Medicine, \\ [S.H.P.], Rainbow Babies and Childrens Hospital, Case Western Reserve University School of Medicine, Cleveland, \\ Ohio, USA
}

\begin{abstract}
Summary
We prospectively evaluated concentrations of $\beta$-D-galactosidase, $\alpha$-L-fucosidase, $\beta$-D- $N$-acetylglucosaminidase, and lysozyme in urine from normal subjects, ambulatory patients with cystic fibrosis (CF), and CF patients with previously normal renal function who were receiving intravenous aminoglycoside (AG) therapy. Enzyme activities were generally low or negligible in subjects not receiving AG. Enzymuria was documented during 12 of 13 AG treatment courses and most frequently involved $\beta$-D- $N$-acetylglucosaminidase excretion. In nine courses, enzymuria occurred in the absence of proteinuria or elevations of blood urea nitrogen and serum creatinine. In three courses attended by enzymuria and evidence of nephrotoxicity, neither the time of appearance nor the magnitude of enzymuria was different from that of nonnephrotoxic patients. In two of these three treatment courses, enzymuria preceded clinical evidence of nephrotoxicity by 16 and 5 days, and in the third course enzymuria and elevation of blood urea nitrogen and serum creatinine occurred simultaneously. We conclude that enzymuria is not a reliable predictor of nephrotoxicity due to $A G$ in CF patients and is not an indication to discontinue AG therapy.
\end{abstract}

\section{Speculation}

Measurement of urinary enzyme excretion after aminoglycoside therapy appears to be too sensitive a test to be clinically useful as a predictor of aminoglycoside-associated nephrotoxicity in patients with cystic fibrosis.

The aminoglycoside (AG) antibiotics are frequently used in the management of serious gram-negative bacterial infections $(4,7$, 8). Drug-induced acute renal tubular damage may preclude a full therapeutic course and in some instances may result in irreversible kidney damage $(2,10,14)$. Current monitoring for renal injury, including urinalysis and measurements of blood urea nitrogen (BUN) and serum creatinine, as well as creatinine clearance, may not detect early changes in renal tubular function. Previous data suggest that an increased excretion of lysosomal enzymes in urine may be a sensitive indicator of AG toxicity and may precede an elevation of BUN and serum creatinine $(5,18,26-28)$.

The purpose of the present investigation is to prospectively evaluate the activities of four glycosidic enzymes $(\beta$-D-galactosidase, $\alpha$-L-fucosidase, $\beta$-D- $N$-acetylglucosaminidase, and lysozyme) in urine as early indicators of AG-associated nephrotoxicity in patients with cystic fibrosis (CF). CF patients were selected for the study population because they are young, generally free of renal disease, and frequently treated with prolonged courses of high-dose intravenous (IV) AG for Pseudomonas aeruginosa lung infection $(29,30)$.

\section{PATIENTS AND METHODS}

Urine specimens were obtained from three groups of patients. Collection of urine specimens for this study was approved by the
Human Experimentation Committee of University Hospitals, Cleveland, $\mathrm{OH}$. Informed consent for use of urine was obtained in all cases.

GROUP A: PATIENTS WITH CF ADMITTED TO RAINBOW BABIES AND CHILDRENS HOSPITAL FOR AG THERAPY OF PSEUDOMONAS LUNG INFECTION

Ten patients, five female, ranging in age from 10 to 34 years, contributed daily first-morning void urine specimens during 13 separate treatment courses. Mean duration of hospitalization was 17 days (range, 11 to 27 days). Clinical scores for these 10 patients ranged from 26 to 78 . This scoring system assigns a maximum of 25 points to each of four categories, including general activity, physical examination, nutrition, and chest roentgenogram, for a best possible total score of 100 points (9). None of the patients was in respiratory failure. None had a history of renal disease. All patients had received previous treatment courses with AG antibiotics, but renal function tests and urinalyses showed no AGrelated nephrotoxicity. Only one study patient had received AG therapy during the 3 months (mean, 13.9 months) before enrollment in this study. This was patient $B$ who was treated with $A G$ less than 1 month after a previous course and became nephrotoxic. Gentamicin (IV) (3 of 13) or tobramycin (10 of 13) therapy was instituted within $24 \mathrm{hr}$ of admission after a baseline urine specimen was obtained. One patient $(\mathrm{C})$ received a single dose of furosemide upon hospital admission; no patients received concomitant cephalosporin therapy. AG doses averaged $11.1 \mathrm{mg} / \mathrm{kg} /$ day $( \pm 0.53$ S.E.) and were administered daily either by an intermittent ( 11 of 13) or continuous infusion regimens. Serum AG concentrations were monitored frequently, and doses were adjusted to maintain therapeutic concentrations (3). Trough AG serum concentrations averaged $1.3 \mu \mathrm{g} / \mathrm{ml}( \pm 0.2$ S.E.) for patients receiving a daily intermittent regimen. For the two patients who received a continuous 24-hr infusion of tobramycin, serum concentrations averaged $5.4 \mu \mathrm{g} / \mathrm{ml}$. No appreciable difference was observed in serum AG concentrations between nephrotoxic and nonnephrotoxic patients.

\section{GROUP B: PATIENTS WITH CF VISITING THE OUTPATIENT CLINIC} FOR ROUTINE INTERVAL EVALUATION

Twenty subjects in this group contributed a single urine specimen. Ages of these patients ranged from 8 to 25 years; six were female. Clinical scores ranged from 33 to 88 . These patients were taking pancreatic enzymes, and some also were taking oral antibiotics. No patient had received IV AG during the preceding 6 months. Although 10 patients had received AGs previously, none had evidence of renal dysfunction.

\section{GROUP C: NORMAL VOLUNTEERS}

Twenty healthy children and adults (11 female), with an age range of 3 to 55 years, contributed a single first-morning void urine specimen. None of these donors was taking medications. Three donors in this group contributed seven consecutive firstmorning voided urine specimens. 
All urine specimens were frozen at $-20^{\circ} \mathrm{C}$ within an hour of collection. Thawed specimens were centrifuged at $1200 \times \mathrm{g}$ for 10 min to remove sediment before enzyme activities were assayed. Assays conducted before and after the freeze-thaw cycle demonstrated that all enzyme activities were stable.

BUN values above 20 , a rise in serum creatinine $>0.5 \mathrm{mg} / \mathrm{dl}$ above baseline, and/or persistent proteinuria were taken as criteria of nephrotoxicity.

\section{METHODS}

BUN and serum creatinine concentrations were determined by autoanalyzer techniques. Serum AG concentrations were measured by radioenzymatic assay (23). Creatinine in urine was assayed by a modification of the Jaffe alkaline picrate reaction (12). All reagents were analytical grade.

$\beta$-D-Galactosidase activity was assayed spectrophotometrically, using $p$-nitrophenyl- $\beta$-D-galactopyranoside (Sigma Chemical Co., St. Louis, MO) as substrate. Substrate was dissolved in $90 \mathrm{mM}$ acetate buffer ( $\mathrm{pH} 4.2)$ to give a reaction concentration of $2.0 \mathrm{mM}$ A $0.2 \mathrm{ml}$ urine sample was added to $0.9 \mathrm{ml}$ of substrate solution. The mixture was agitated and then incubated for $60 \mathrm{~min}$ at $37^{\circ} \mathrm{C}$. The reaction was stopped by adding $1.0 \mathrm{ml}$ of $3 \mathrm{M} \mathrm{NaOH}$ Absorbance was measured at $420 \mathrm{~nm}$, and results were calculated using a molar extinction coefficient of 13,900 .

$\alpha$-L-Fucosidase was assayed similarly with $p$-nitrophenyl- $\alpha$-Lfucopyranoside (Pierce Chemical Co., Rockford, IL) dissolved in $15 \mathrm{mM}$ citrate-phosphate buffer ( $\mathrm{pH}$ 6.0) to a reaction concentration of $3.0 \mathrm{mM}$. Reactions proceeded for $90 \mathrm{~min}$.

$\beta$-D-N-acetylglucosaminidase was also assayed by liberation of $p$-nitrophenol from the $\beta$-D- $N$-acetyl-glucosaminopyranoside (Sigma Chemical Co.). Substrate concentration was $5 \mathrm{mM}$ (reaction mixture) in $50 \mathrm{mM}$ citrate-phosphate buffer ( $\mathrm{pH} \mathrm{4.2).} \mathrm{Reac-}$ tions were carried out for $30 \mathrm{~min}$. Before $\beta$-hexosminidase assay, a low molecular weight inhibitor of the enzyme was removed by gel filtration of urine on Sephadex G-25 (17).

Units of activity for the three lysosomal enzymes are defined as umoles of $p$-nitrophenol liberated per $\mathrm{mg}$ of urine creatinine.

Lysozyme was assayed on a Gilford recording spectrophotometer by a modification of the method of Smolelis and Hartsell (24). The initial rate of lysis of Micrococcus lysodeikticus organisms in suspension was monitored. Units were expressed as equivalents of egg white lysozyme in $\mu \mathrm{g} / \mathrm{mg}$ of urine creatinine. All four glycosidase assays were linear with respect to time and amount of urine used in the assays.

Enzymuria was arbitrarily defined as at least two consecutive urine enzyme activities greater than two standard deviations (S.D.) above the mean activity level of $C F$ patient not receiving $A G$.

\section{RESULTS}

Enzyme activities in the urine of 20 healthy control subjects, 20 stable ambulatory patients with $\mathrm{CF}$, and 10 patients with $\mathrm{CF}$ immediately before initiation of 11 courses of $A G$ therapy are depicted in Figure 1. Enzyme activities generally were negligible or low in all three groups, although patients with CF occasionally had higher than normal activities of $\beta$-D- $N$-acetylglucosaminidase or $\beta$-D-galactosidase activity. Urine samples with baseline values above 0.5 units for $\beta$-D-galactosidase and $\beta$-D- $N$-acetyl-glucosaminidase were from patients who had received AGs previously. There was minimal lysozyme activity $(<2 \mu \mathrm{g} / \mathrm{ml} / \mathrm{mg}$ creatinine) in urine samples from all three baseline groups. No appreciable day-to-day variation was noted when daily first morning urine specimens from three healthy subjects were analyzed for activities of all four enzymes.

Figures 2 to 5 show excretion of $\beta$-D- $N$-acetylglucosaminidase, $\beta$-D-galactosidase, $\alpha$-L-fucosidase, and lysozyme in daily firstmorning void urine samples of patients before and during $A G$ therapy. The levels of lysosomal enzymes in the urine frequently increased within 1 to 3 days after initiation of $A G$ therapy, and increased levels often persisted for the duration of therapy (Figs. 2 to 4). In contrast, urine lysozyme activity (Fig. 5) usually was undetectable during the first wk of $A G$ therapy and was not elevated in any patient until the fourth day of therapy. The earliest rise in lysozyme activity was seen in patient B who simultaneously showed evidence of nephrotoxicity (elevated BUN and serum creatinine).

$\beta$-D- $N$-Acetylglucosaminidase was elevated in the urine during 12 of 13 treatment courses, $\beta$-galactosidase, and $\alpha$-fucosidase in 10 , and lysozyme in 5. Proteinuria or elevations of BUN and serum creatinine developed during three of 13 treatment courses.

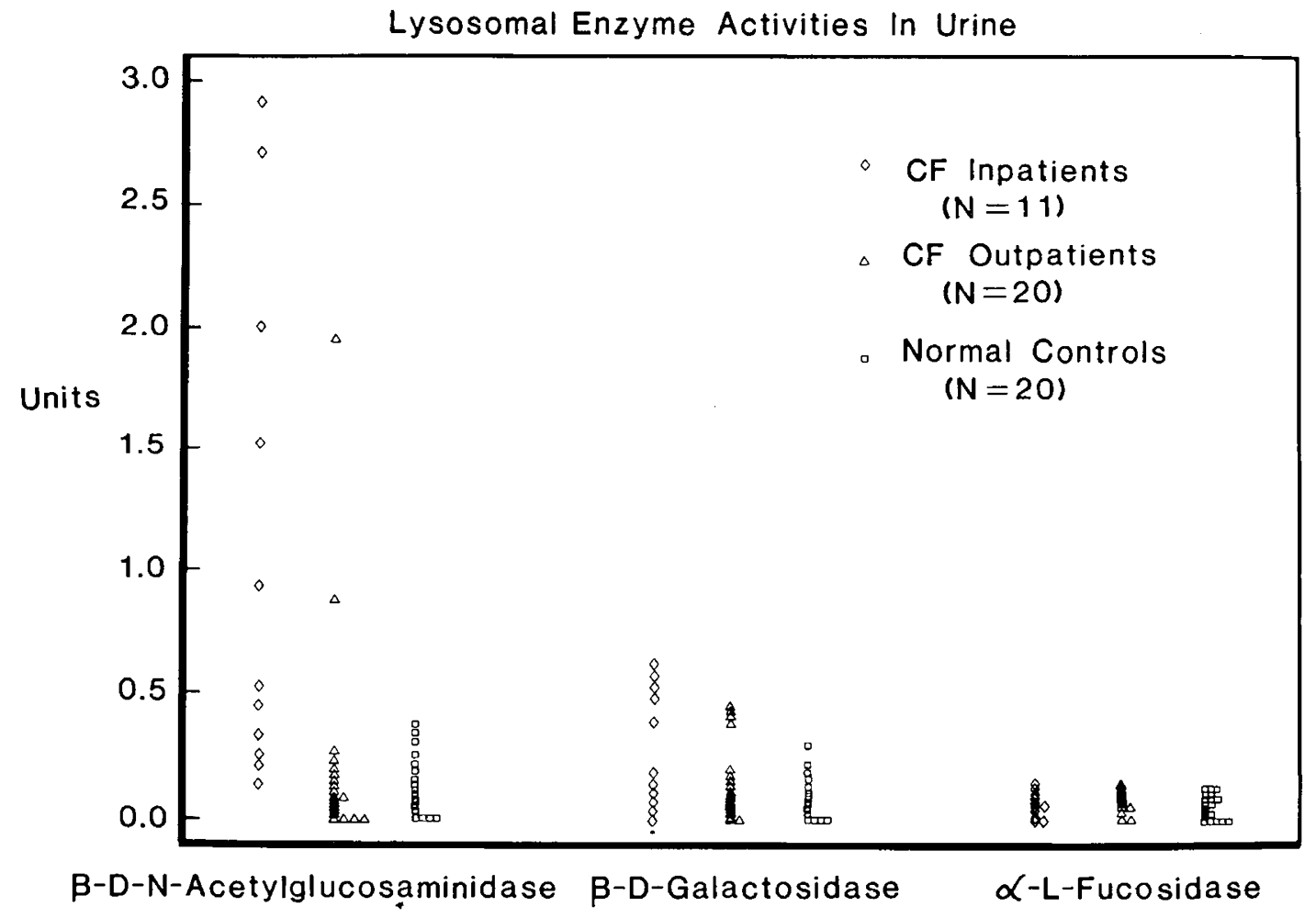

Fig. I. Initial (baseline) lysosomal enzyme activities in urine. A baseline urine for CF in-patients was not available for two of 13 treatment courses. 


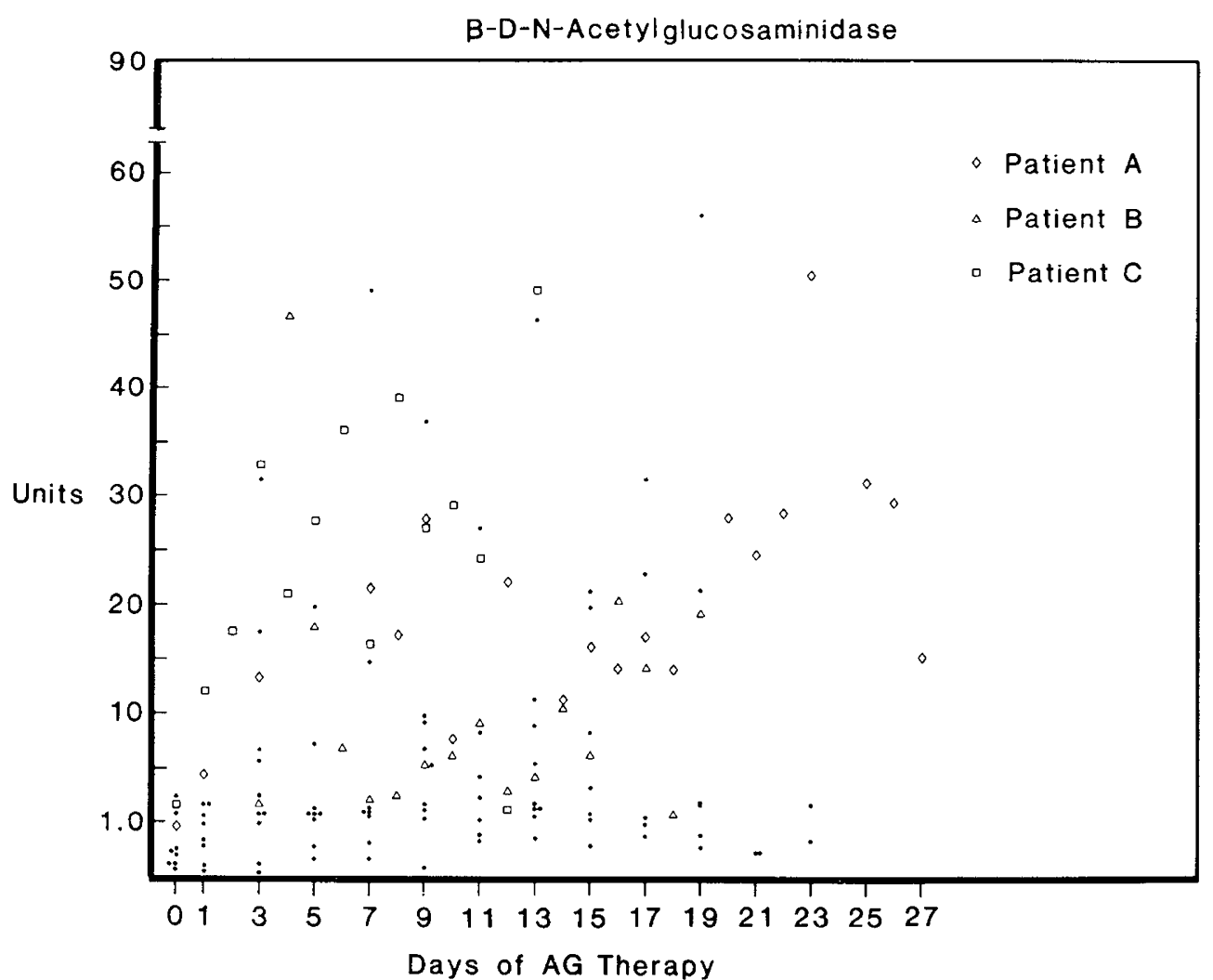

Fig. 2. Serial determinations of $\beta$-D-N-acetylglucosaminidase for 13 AG treatment courses in 10 patients with $\mathrm{CF}$. Values for nonnephrotoxic patients are depicted on alternate days and those for nephrotoxic patients $(A, B$, and $C)$ daily.

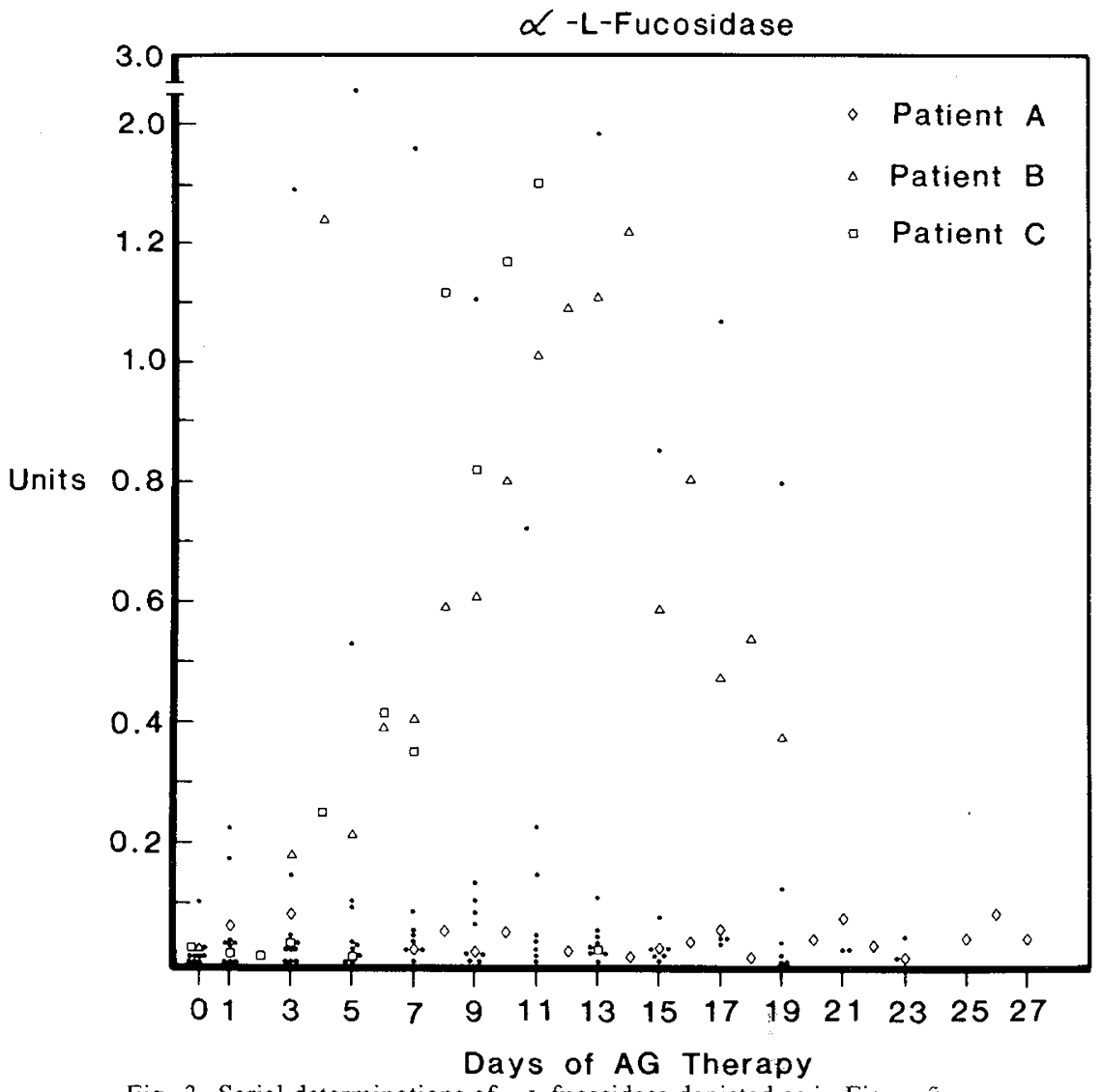

Fig. 3. Serial determinations of $\alpha$-L-fucosidase depicted as in Figure 2.

In the three courses attended by evidence of nephrotoxicity, enzymuria preceeded other evidence of renal toxicity by $1<$ to 16 days. Nine treatment courses were characterized by enzymuria but no other evidence of renal injury. The magnitude of enzymuria in these nine tretment courses was in some cases lower than and in some cases equivalent to that of patients who became nephrotoxic. No diurnal variation of any enzyme activity was observed wher all urine specimens ( 3 to $4 /$ day) were collected from one 


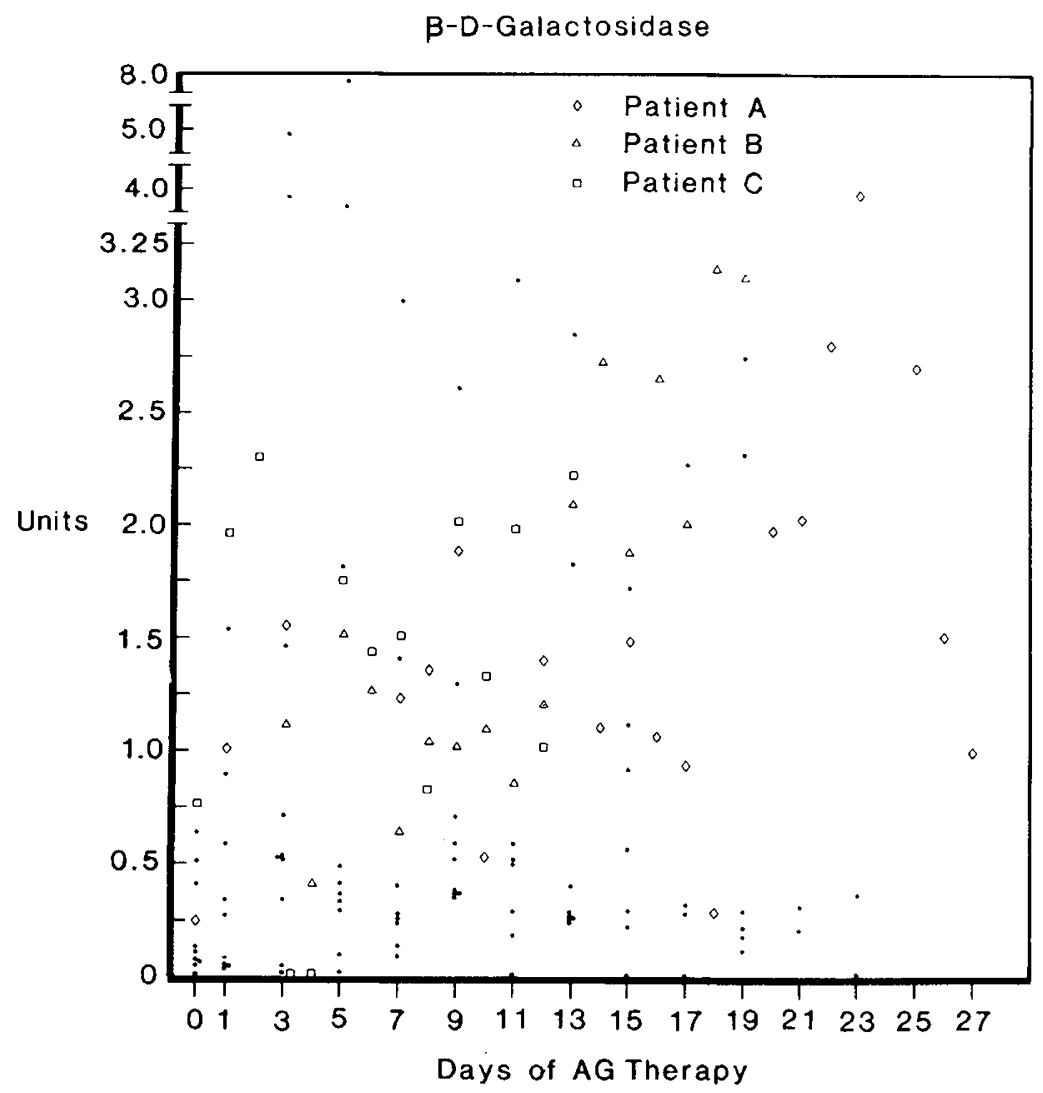

Fig. 4. Serial determinations of $\beta$-D-galactosidase depicted as in Figure 2.

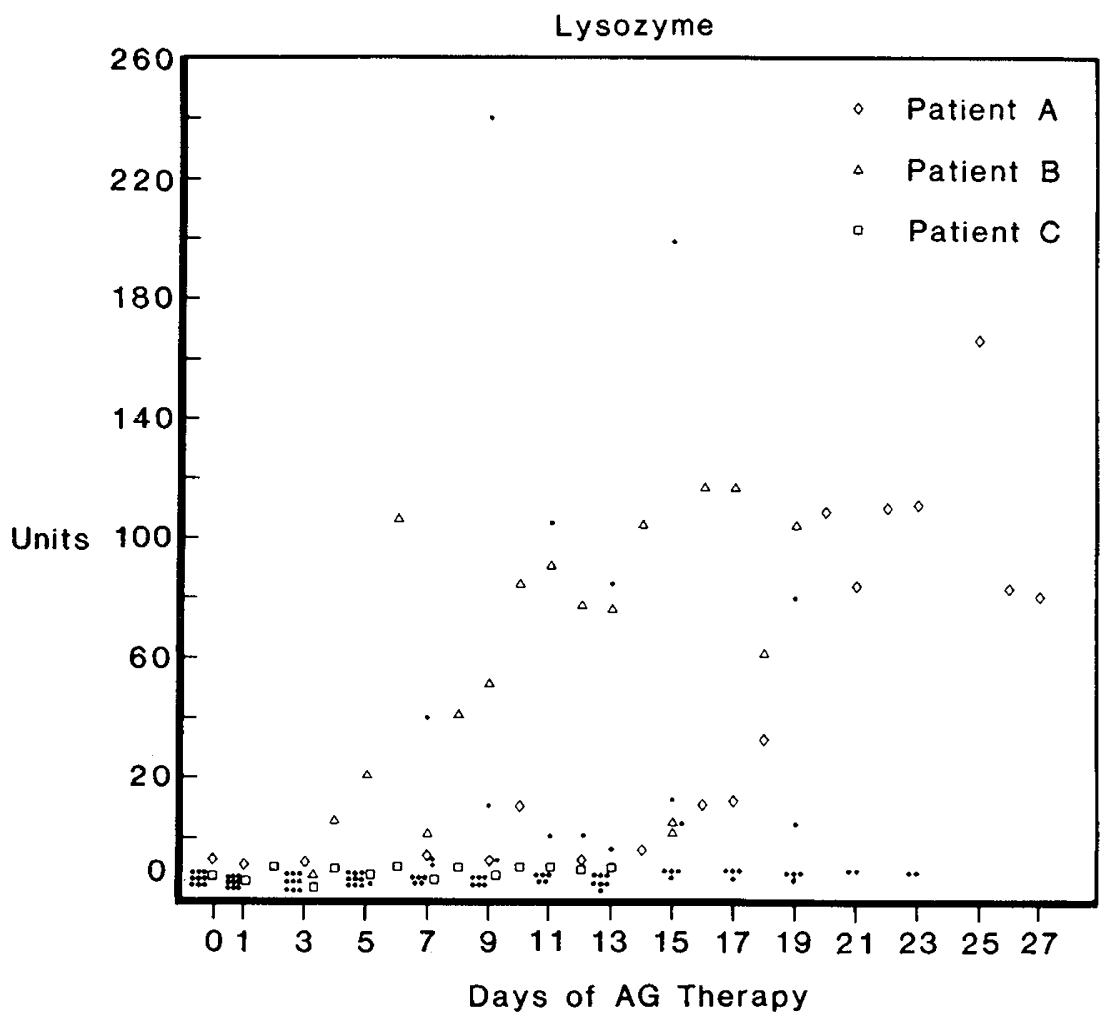

Fig. 5. Serial determinations of lysozyme depicted as in Figure 2.

nonnephrotoxic patient with CF during a 14-day course of AG therapy.

Figure 6 illustrates the data obtained from patient $A$ who developed a reduction in renal function during prolonged therapy. with gentamicin $(7.5 \mathrm{mg} / \mathrm{kg} /$ day $)$. No elevation of $\alpha$-L-fucosidase activity in the urine was detected throughout the course of therapy.
$\beta$-D-Galactosidase and $\beta$-D- $N$-acetylglucosaminidase activities increased early after initiation of therapy, plateaued, and then increased further after a rise in the serum creatinine. Initial elevations of $\beta$-D-galactosidase and $\beta$-D- $N$-acetylglucosaminidase preceeded an elevation in serum creatinine by 16 days. Lysozyme activity in urine was baseline throughout the first 2 wk of therapy 


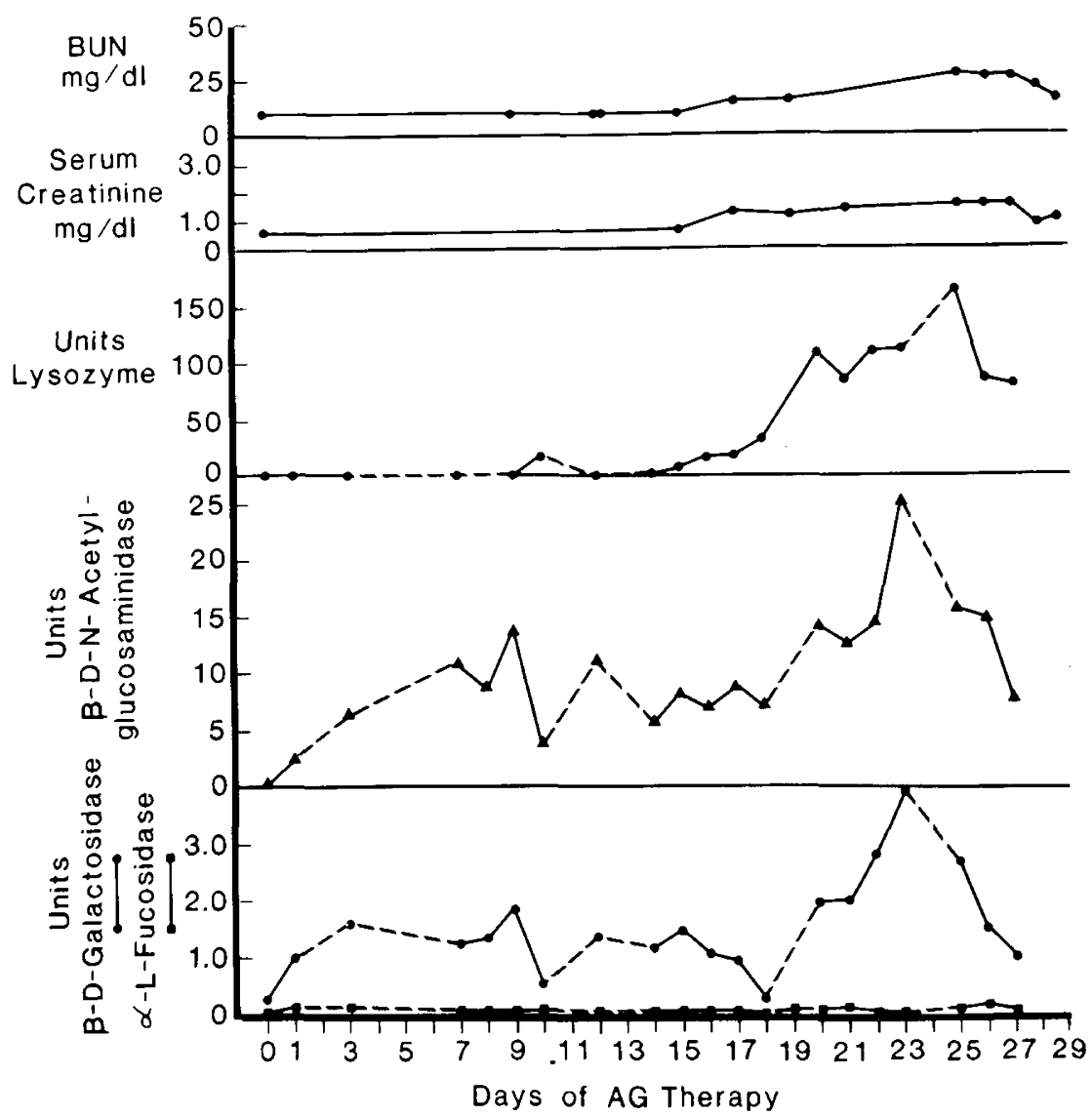

Fig. 6. Results of renal function and enzymuria data for Patient A, a 16-year-old white male with CF (clinical score, 30) receiving $7.5 \mathrm{mg} / \mathrm{kg} / \mathrm{day}$ of gentamicin IV. Evidence of clinical nephrotoxicity was first observed on day 17 of AG therapy.

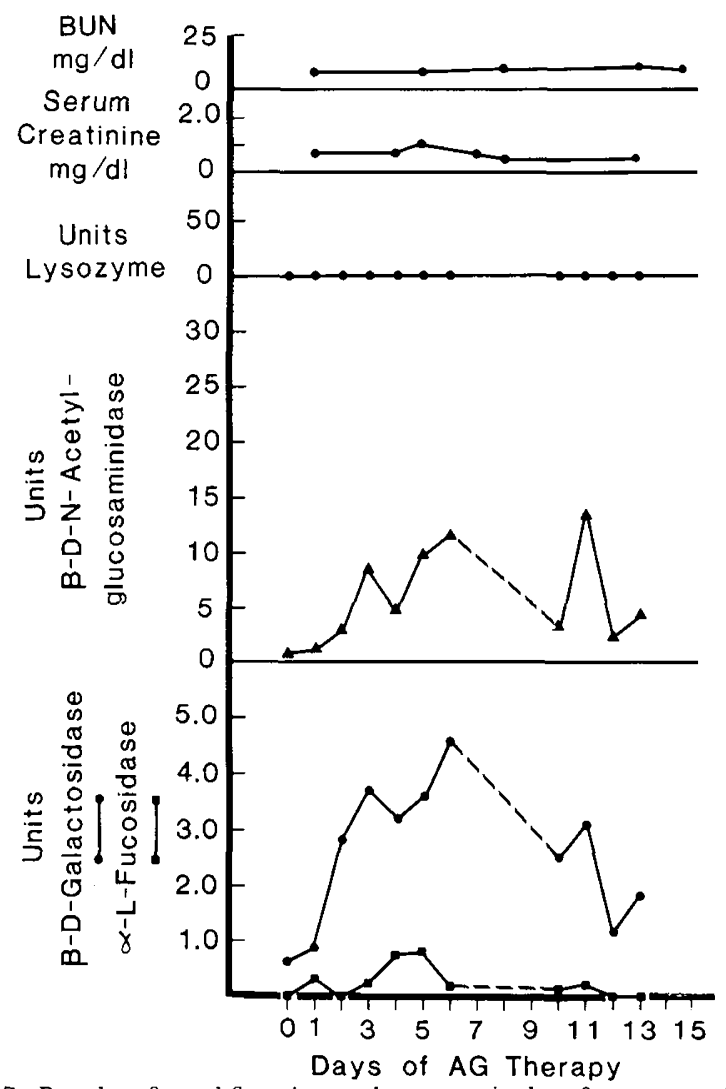

Fig. 7. Results of renal function and enzymuria data for a nontoxic 20year-old white female with $\mathrm{CF}$ (clinical score, 65 ) receiving $9.6 \mathrm{mg} / \mathrm{kg}$ / day of tobramicin IV. On days 1 and 8 of AG therapy, 24-hr creatinine clearance determinations were 130 and $110 \mathrm{cc} / \mathrm{min}$, respectively. but slowly increased, concomitant with the rise in serum creatinine and BUN. Abnormal renal function and enzymuria occurred simultaneously in patient B, 4 days after initiation of therapy. Patient $C$ developed nephrotoxicity (persistent proteinuria) approximately 5 days after elevation of $\beta$-D-galactosidase $\alpha$-L-fucosidase, and $\beta-\mathrm{D}-N$-acetylglucosaminidase. No elevation of lysozyme activity was noted in the urine of patient $C$.

Figure 7 illustrates the enzyme activity data obtained from another CF patient, who received 14 days of tobramycin therapy $(9.6 \mathrm{mg} / \mathrm{kg} /$ day) and showed no evidence of nephrotoxicity. Activity of $\alpha$-L-fucosidase was slightly greater than that observed with the nephrotoxic patient A (Fig. 6). Patterns of $\beta$-D-galactosidase and $\beta$-D- $N$-acetylglucosaminidase excretion were very similar to that of patient $A$ in that high levels were attained within 48 to $72 \mathrm{hr}$ after AG therapy was started. Lysozyme activity was undetectable throughout the course of therapy.

\section{DISCUSSION}

Several investigators have documented the excretion of increased amounts of lysosomal enzymes, lysozyme, or $\beta_{2}$-microglobulin in the urine of patients with renal injury $(11,13,19,20$ $22,25)$. Most investigators agree that enzymuria results from release of lysosomal or other soluble enzymes by injured tubular cells. Although enzymuria may be a sensitive indicator of renal injury, not all patients with demonstrable renal disease display enzymuria (16). Conversely, enzymuria may occur in the absence of other indices of renal dysfunction. For example, high mean activities of lysozyme, $\beta$-D- $N$-acetylglucosaminidase, and $\beta$-glucuronidase may be detected in the urine of children receiving gentamicin, despite the fact that serum creatinine or BUN are unchanged (1). Thus, monitoring urinary enzyme excretion may not discriminate $A G$ recipients who are and who are not destined to develop renal dysfunction.

The major site of AG toxic effects in the kidney is the proximal 
tubule $(6,15)$. Release of tubular cell proteins into urine has been proposed as a sensitive indicator of $A G$ toxicity. Preliminary observations suggest that activities of the glycosidases rise dramatically several days before elevation of serum creatinine in patients with AG-associated nephrotoxicity (28). Patients with renal allografts who receive gentamicin respond uniformly with enzymuria within 1 to 2 days, followed 10 days later by elevations of serum creatinine in $75 \%$ of cases (27). These studies suggest that the appearance of enzymuria is predictive of severe renal injury and may be a useful guide in avoiding serious toxicity. However, longitudinal observations of the relationship between enzymuria and decreased renal function are lacking for patients with normal kidneys who require therapy with AG. This study was designed to document prospectively this relationship in patients with CF and normal renal function.

Enzymuria, defined by two consecutive enzyme levels greater than 2 S.D. above the mean for baseline values in the patient group was observed during 12 of 13 courses of $A G$ therapy in $C F$ subjects. Only two of these subjects developed decreased renal clearance as evidenced by a rising serum creatinine, and a third subject developed proteinuria. Enzymuria preceeded other evidence of renal toxicity by intervals of 5 days, and approximately 16 days in two of these three patients and occurred simultaneously with elevation of BUN and serum creatinine in the third patient. Activities of all four enzymes were elevated in only one nephrotoxic patient, lysozyme activity being normal in one and $\alpha$-Lfucosidase activity in another. No consistent pattern of enzyme excretion could be determined by study of this limited number of nephrotoxic patients. However, elevation of lysozyme activity did occur concurrently with toxicity in two patients. Therefore urinary lysozyme activity was not a predictor of nephrotoxicity.

Nine patients who developed enzymuria during a course of $\mathrm{AG}$ therapy exhibited no further evidence of renal dysfunction. The magnitude of enzymuria was generally less than that of nephrotoxic patients, although two nonnephrotoxic patients (14- and 21 day therapy courses) had concentrations of the lysosomal enzymes in the same range as those of nephrotoxic patients. Patients with enzymuria only were continued on $A G$ therapy at therapeutic dosages for intervals between 9 and 23 days without emergence of proteinuria or elevated concentrations of serum creatinine and BUN. Our data indicate that assessment of enzymuria may be too sensitive to be a useful clinical indicator of $A G$ nephrotoxicity $\mathrm{AG}$ administration need not be discontinued as soon as enzymuria is detected because clinically important renal toxicity may not occur. Furthermore, in our experience, a rise in serum creatinine and/or BUN is usually reversible after discontinuation of the drug.

Additional data are needed to determine whether repeated episodes of AG-related enzymuria will predict the development of renal dysfunction during subsequent courses of AG. Extrapolation of this experience to other patient groups should be carried out with caution. However, we know of no evidence that $\mathrm{CF}$ patients are less susceptible to $A G$ nephrotoxicity than other patients with intact renal function.

Enzymuria is not a clearly reliable predictor or indicator of AG-associated renal dysfunction. Until a more useful predictor of renal dysfunction is available, careful monitoring of serum AG concentrations and repeated observations for proteinuria, sloughing of renal tubular cells, and elevations of BUN and serum creatinine are indicated to detect renal dysfunction at an early stage and to avoid serious AG-related nephrotoxicity.

\section{REFERENCES AND NOTES}

1. Adelman, R. D., and Zakauddin, S.: Urinary enzyme activity in children and neonates receiving gentamicin therapy. Dev. Pharmacol. Ther., $l: 325$ (1980)

2. Apple, G. B., and Neu, H. C.: Nephrotoxicity of antimicrobial agents. N. Engl.
J. Med., 196: 722 (1977)

3. Barza, M., and Lauerman, M.: Why monitor serum levels of gentamicin? Clin Pharmacokinet., 3: 202 (1978).

4. Barza, M., and Scheife, R. T.: Antimicrobial spectrum, pharmacology and therapeutic use of antibiotics. Part 4: Aminoglycosides. Am. J. Hosp. Pharm., 34: 723 (1977).

5. Beck, P. R., Thompson, R. B., and Chaudhuri, A. K. R.: Aminoglycoside antibiotics and renal function: changes in urinary $\alpha$-glutamyltransferase excretion. J. Clin. Pathol., 30: 432 (1977).

6. Bennett, W. M., Gilbert, D. N., Houghton, D., and Porter, G. A.: Gentamicin nephrotoxicity: morphologic and pharmacologic features. West. J. Med., 126: 65 (1977).

7. Boxerbaum, B., Pittman, S.. Doershuk, C. F., Stern,. R. C., and Matthews, L. W.: Use of gentamicin in children with cystic fibrosis. J. Infect. Dis., 124: S293 (1971).

8. Crozier, D. N., and Khan, S. R.: Tobramycin in treatment of infections due to Pseudomonas aeruginosa in patients with cystic fibrosis. J. Infect. Dis., 134: $\mathrm{S} 187$ (1976).

9. Doershuk, C. F. Matthews, L. W . Tucker, A. S Nudelman, H., Eddy, G., Wise, M., and Spector, S.: A 5-year clinical evaluation of a therapeutic program for patients with cystic fibrosis. J. Pediatr., 65: 677 (1964).

10. Gary, N. E., Bozzeo, L., Salaki, J., and Eisinger, R. P.: Gentamicin-associated acute renal failure. Arch. Intern. Med., 136: 1101 (1976).

11. Gonick, H. C., Kramer, H. J., and Shapiro, A. E.: Urinary $\beta$-glucuronidase activity in renal disease. Arch. Intern. Med. 132: 63 (1973).

12. Hare, R. S.: Endogenous creatinine in serum and urine. Proc. Soc. Exp. Biol. Med., 74: 148 (1950)

13. Hayslett, J. P., Perillie, P. E., and Finch, S. C.: Urinary muramidase and renal disease: correlation with renal histology and implication for the mechanism of enzymuria. N. Engl. J. Med., 279: 506 (1968).

14. Hewitt, W. L.: Gentamicin toxicity in perspective, Postgrad. Med. J., 50(Suppl. 7): 55 (1974).

15. Houghton, D. C., Hartnett, M., Campbell-Boswell, M., Porter, G., and Bennett, W.: A light and electron microscopic analysis of gentamicin nephrotoxicity in rats. Am. J. Pathol., 82: 589 (1976).

16. Kunin, C. M., Russell, R. W., Craig, W. A., England, A. C., and DeAngelis, C.: Enzymuria as a marker of renal injury and disease: Studies of $N$-acetyl- $\beta$ glucosaminidase in the general population and in patients with renal disease. Pediatrics, 62: 751 (1978).

17. Maruhn, D.: Rapid colorimetric assay of $\beta$-galactosidase and $N$-acetyl- $\beta$-glucosaminidase in human urine. Clin. Chim. Acta. 73: 453 (1976).

18. Patel, V., Luft. F. C., Yum, M. N.. Patel, B., Zeman, W.. and Kleit, S. A.: Enzymuria in gentamicin-induced kidney damage. Antimicrob. Agents Chemother. 7: 364 (1975)

19. Pockop, D. J., and Davidson, W. D.: A study of urinary and serum lysozyme in patients with renal disease. N. Engl. J. Med., 270: 269 (1964).

20. Robinson, D., Price, R. G., and Dance, N.: Rat-urine glycosidases and kidney damage. Biochem. J., 102: 533 (1967).

21. Schapiro, A., Paul, W., and Gonick, H.: Urinary $\beta$-glucuronidase in urologic diseases of the kidneys. J. Urol., 100: 146 (1968).

22. Schentag, J. J., Sutfin, T. A., Plaut, M. E., and Jusko, W. J.: Early detection of aminoglycoside nephrotoxicity with urinary $\beta$-2-microglobulin. J. Med., 9: 201 (1978).

23. Smith, D. H., Van Otto, B., and Smith, A. L.: A rapid chemical assay for gentamicin. N. Engl. J. Med., 286: 583 (1972)

24. Smolelis, A. N., and Hartsell, S. E.: The determination of lysozyme. J. Bacteriol., 58: 731 (1949)

25. Stroo, W. E., and Hook, J. B.: Enzymes of renal origin in urine as indicators of nephrotoxicity. Toxicol. Appl. Pharmacol., 39: 423, (1977).

26. Wellwood, J. M., Lovell, D. Thompson. A. E., and Tighe. J. R.: Renal damage caused by gentamicin: a study of the effects on renal morphology and urinary enzyme excretion. J. Pathol., 118: 171 (1976).

27. Wellwood, J. M., Simpson, P. M., Tighe, J. R., and Thompson, A. E.: Evidence of gentamicin nephrotoxicity in patients with renal allografts. Br. Med. J., 3: 278 (1975).

28. Wilson. D., Weinstein, A., Hall, P., and Vidt, D.: Early indicators of aminoglycoside nephrotoxicity. Clin. Pharmacol. Ther., (Abstract), 25: 253 (1979).

29. Wood, R. E.: Cystic fibrosis: diagnosis, treatment, and prognosis. South. Med. J., 72: $189(1979)$

30. Wood, R. E., Boat, T. F., and Doershuk, C. F.: State of the art: cystic fibrosis. Am. Rev. Respir. Dis., 113: 833 (1976).

31. Portions of this work appeared in abstract at the Society for Pediatric Research April 1979, and Cystic Fibrosis Club, May 1979.

32. The authors wish to express their appreciation to the nursing and house staff at Rainbow Babies and Childrens Hospital for their assistance with sample collection.

33. Requests for reprints should be addressed to: Thomas F. Boat. M.D., Department of Pediatrics. Rainbow Babies and Childrens Hospital, 2101 Adelbert Road, Cleveland, $\mathrm{OH} 44106$ (USA).

34. This research was supported in part by USPHS grant AM-08305.

35. Received for publication August 29, 1980.

36. Accepted for publication February 2, 1981 